\title{
Trace Elements Assessment in Human Nails in Eastern Sudan Using Atomic Absorption Spectroscopy
}

\author{
Salwa M. Ibrahim1, Abdelrazig M. Abdelbagi2,3, ALi E. Sharf Eldeen" \\ ${ }^{1}$ Science College, Sudan University for Science and Technology, Khartoum, Sudan \\ ${ }^{2}$ Physics Department, Science College, Shaqra University, Dawadami, Riyadh, KSA \\ ${ }^{3}$ Faculty of Science, Omdurman Islamic University, Omdurman, Sudan \\ ${ }^{4}$ Faculty of Science, Khartoum University, Khartoum, Sudan \\ Email: salwa22334455@hotmail.com, razig2000@hotmail.com
}

Received 15 January 2014; revised 15 February 2014; accepted 22 February 2014

Copyright (C) 2014 by authors and Scientific Research Publishing Inc.

This work is licensed under the Creative Commons Attribution International License (CC BY). http://creativecommons.org/licenses/by/4.0/

(c) (i) Open Access

\begin{abstract}
In the present work, elements concentration in fingernails samples of volunteers of different ages (males, females) were determined using atomic absorption spectroscopy (AAS) Perkin-Elmer, spectrophotometer. Fingernails samples of different groups were analyzed to determine the trace elements $\mathrm{Ca}, \mathrm{Mg}, \mathrm{Mn}, \mathrm{Fe}, \mathrm{Ni}, \mathrm{Cu}, \mathrm{Co}, \mathrm{Zn}$ and $\mathrm{Pb}$. Standards materials were prepared for concentration assessment that adjacent to samples from two cities in different location in eastern province of Sudan for elements concentrations finding. In addition, samples of hands fingernails and toenails were analyzed for comparison and method validation. Consequently, the significant levels of elements concentration in nails samples of Jabiat residents compared to Port Sudan resident's area due to soil dispersion are supporting the possibility of external contamination. The data of component matrix and rotated component matrix of varimax normalization using principal component analysis revealed important predictors of nails elements $\mathrm{Mg}, \mathrm{Mn}, \mathrm{Fe}, \mathrm{Cu}$ and $\mathrm{Zn}$ concentrations in soil of both areas under study. However, the $\mathrm{Pb}, \mathrm{Ni}, \mathrm{Ca}$, and $\mathrm{Co}$ are possible to be indication of different sources associated with environmental contamination. The significant correlation and principal component analysis of the elements of nails concentrations in the two categories supported the probability of different expose environmental contamination.
\end{abstract}

\section{Keywords}

Trace Elements; Nails; Geographical Location; Atomic Absorption Spectrophotometer

How to cite this paper: Ibrahim, S.M., Abdelbagi, A.M. and Eldeen, A.E.S. (2014) Trace Elements Assessment in Human Nails in Eastern Sudan Using Atomic Absorption Spectroscopy. Journal of Analytical Sciences, Methods and Instrumentation, 4, 1-8. http://dx.doi.org/10.4236/jasmi.2014.41001 


\section{Introduction}

Since ancient times, the nails growth is used as an indicator of health and physiological imbalances of human. The fingernails and toenails are used as indication of aging, in addition of various properties, such as thickening, thinning, discoloration, splitting, grooves concave and convex shape so that flatness can be used as indicate disease in the body, nutrient deficiencies, drug reaction and poisoning or nail injury. The nails thickness change or loosened and infected with bacteria are illness signed of certain disease [1]. The human nail is permeable than skin and the composition consists of $7 \%-12 \%$ of water, so that it is a solid part in body. Mechanical pressure on nails can cause harmful pain; also the nails are affected with stretched, tight and cosmetics. Nails after growth is remain isolated from other metabolic activities in the human body, which is considered as a good reflection of long-term exposure (Takagi et al. 1988). The advantages of nails in elements evaluation are preferable biologic medium because of ease of collection, storage convenience, ease of handling and reproducibility of later analysis results. The nails from various fingers in feet and hands are growth in several weeks of time between formation and clipping and that indicates exposure to elevated concentration contamination integrated over a 2 - 12 month period (Hunter 1990).

The trace elements levels in nails are subject of interest in the biomedical and environmental sciences since recent years. Nails measurement remains the subject of interest as indices for assessing nutritional status, diagnosing diseases, identifying systemic intoxication and environmental exposures. The determination of elements contents in the nails can be considered as an indicator of level in other tissues and that reflect mineral metabolism in the body [2] [3].

The measurement of elements in nails is used as biomarker for exposure, so that the appropriate selection of these elements is of critical importance for health care management purposes, public health decision making, and primary prevention activities [4]. Significant result may lead to develop a better and easy diagnostic measure about metal toxicity particularly as serving program for data recording. Thus, nails can be considered as an excretory product, the trace element contents of which reflect mineral metabolism in the body and leads to contentious data record for many people leading to many valuable properties [5] [6]. The nails human elements concentrations in east district of Sudan relative to the long term source exposure have not been established yet. In these work elements concentration investigation in nails population has possible risk factors exposure to surface soil, drinking water, types of food and other environmental sources [7]. The purpose of this study was to find out a base line information concerning levels of elements exposure in the nails in our population, since previously no reported data are available in this regard in our area [8].

\section{Experimental Methods}

Groups were categorized on geographical location, types of nails. The group's samples were collected from east province of Sudan from various groups of males and females and the climate supposed to be similar in the two cities. In addition, to the underground drinking water is that relative to same source of expose to elements for both sites. Two cities was selected area relative to different criteria such as soil and food, beside the geographical location area with similar demographic characteristics to the exposed area that is indicate elevated concentrations of these elements in the environment [9].

\subsection{The Study Area}

Jabiat is part of the red sea hills area and about $380 \mathrm{~km}$ far from main national harbor Port Sudan on the red sea coast. The Jabiat district is the east of the red sea coast in the same region of east of Sudan. The secondary chain of hills is separated by sandy valley in the region, which joins Khaour Ariab and Wadi Amur. The climate in the region from June to September is hot season, but in Jabit is moderate. The January and February is coolest period in the region. There are two types of winds in the area and that from the west or northwest during the summer, which is depending on the season and from north or northeast. The Ariab gold mining in the area is closed to Jabiat about $3 \mathrm{~km}$ in circle of $25 \mathrm{~km}$ diameter and the mineralization of gossans and massive sulphide in main geological locality of the area. The geological history reflect the formation of plutonic rock and oldest contemporaneous with the volcano sedimentary units. Sulphide mineralization is consists of massive pyrite with particular metals and variable $\mathrm{Cu}$ and $\mathrm{Zn}$ grades and gold a main possible content of arid part of province, which is surrounding Jabiat [10]. 
Nails samples from various groups were collected from Port Sudan and Jabiat sites.Hands fingernails and toenails were collected from females and males living in different area and of age ranging between 14 - 40 years. The samples were collected from the groups at interval of 2 to 3 weeks, stored in glass containers and then divided relative to localities, gender, ages and an acquired from two subjects as mention. Nails samples collection may seem a relatively simple task and can be easily being obtained from the individuals and there are no significant spatial and temporal variations [11]. The sets of samples are used as a subject of interest and comparable statistical analysis, as well as supporting the validity and reliability of the collected data.

\subsection{Samples Preparation}

The nails samples were cleaned manually and all visible dirt on the surface removed, and then was washing with water-acetone solution. In the cleaning process of samples the solution of water $50 \%$ and acetone $50 \%$ were used to remove all types of exogenous contamination, from fats and lipids to various other organic or inorganic substances as recommended by the International Atomic Energy Agency (IAEA, 1985) [12]. Therefore, the heavy metals do not affect with washing procedures to remove the external contaminants due to strong complex with the groups, which is essentially influenced their concentration in the nails sample (Chen et al., 1999), Mikasa et al. (1988) [13] [14].

Decomposition of heavy metals in nails is very important in determination of these elements by using a mixture of nitric acid $\left(\mathrm{HNO}_{3}\right)$ with hydrogen peroxide $\left(\mathrm{H}_{2} \mathrm{O}_{2}\right)$ or nitric acid only (Samanta et al., 1999; Chen et al., 1999; Puchyr et al., 1998).

Firstly, standard solutions of each element were prepared by using an amount of $250 \mu \mathrm{L}$ that was taken from the stock standard solution $(1000 \mathrm{mg} / \mathrm{L})$ in a plastic volumetric flask $(25 \mathrm{ml})$ and full up to the mark with 0.5 Normality of hydrochloric acid solution, thus the intermediate amount of standard solution is (10 mg). Secondly, the standard solutions for measurement were prepared to suitable concentration of each element of Ca and Mg in the sample solution. Calcium and Magnesium stock solutions (100 ppm) were taken in a series of $10 \mathrm{ml}$ of plastic volumetric flack that full up to the marks with 0.5 N HCL solution. The solution of Ca and Mg were folded by strontium to prevent interference and the final concentration of series of different amount of Ca and $\mathrm{Mg}$ prepared respectively [15].

The standards of $\mathrm{Mn}, \mathrm{Fe}, \mathrm{Cu}, \mathrm{Ni}, \mathrm{Co}, \mathrm{Zn}$, and $\mathrm{Pb}$ determined by using a series of different concentration were taken from the intermediate standard solution $(10 \mathrm{mg} / \mathrm{L})$. The solutions of the elements were filled up to the marks of $0.5 \mathrm{~N} \mathrm{HCL}$, which was similar to the solvent of the sample and that to avoid the physical interference, corresponding to concentration of previous elements respectively.

\section{Results and Discussion}

Assessments of elements concentration in nails and standards samples are largely based on instrumental Atomic Absorption Spectroscopy elements identification technique in hands and feet nails used [16]. The results were obtained clearly indicate that nails concentration of heavy metals can be used as an indication of many properties such as heavy metal exposure related to a geographical location and soil, drinking water, type of food and may be some certain diseases [17]. The both Figures 1 and 2 are graphically displayed the main elements contents in the nails of Sudanese's males and females of different ages. Relation of elements concentration of nails in Jabiat area is showed higher concentration of $\mathrm{Mn}, \mathrm{Mg}, \mathrm{Fe}, \mathrm{Ni}, \mathrm{Cu}, \mathrm{Co}, \mathrm{Zn}$ and $\mathrm{Pb}$ with the comparison of Port Sudan area except for Ca in Figures 3 and 4.

The Port Sudan site is revealed the lowest elemental contamination as compared to the Jabait site, which includes the major sources of this site, may be affected with geographical location, soil dispersion and underground drinking water. The elements concentration in nails groups due to residents areas in the east part of Sudan are highly relative to the natural geographical condition and presence of contamination resulting from living activities, environmental sources and underground drinking water [18].

Figures 5 and 6 shows elements average concentration of feet nails are compared with hands fingernails for all individuals.

The data of fingernails of feet and hands with comparison of available value and the literature reveals the levels of elements $\mathrm{Ca}, \mathrm{Mg}, \mathrm{Mn}, \mathrm{Fe}, \mathrm{Cu}, \mathrm{Ni}, \mathrm{Co}, \mathrm{Zn}$ and $\mathrm{Pb}$ in the nails samples of feet higher than in hands [19]. The elements level in nails sample was potentially elevated by the absorption of such elements from soil dispersion and underground drinking water in the area and other environmental factors [20]. The toenails are 


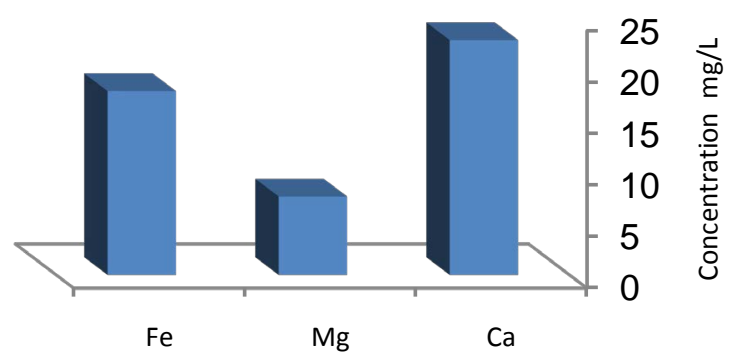

Elements

Figure 1. Elements average concentrations of nails.

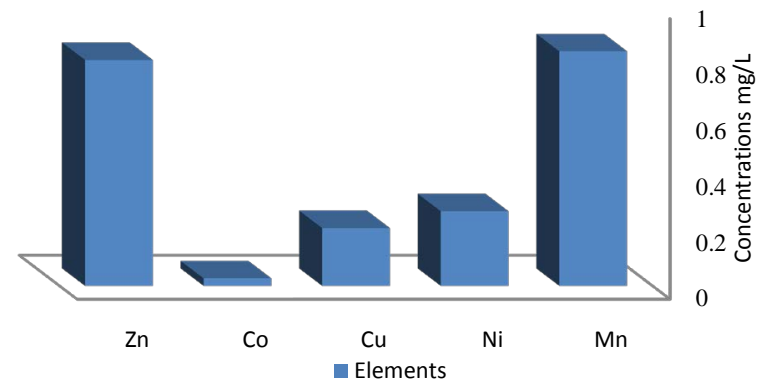

Figure 2. Elements average concentrations of nails.

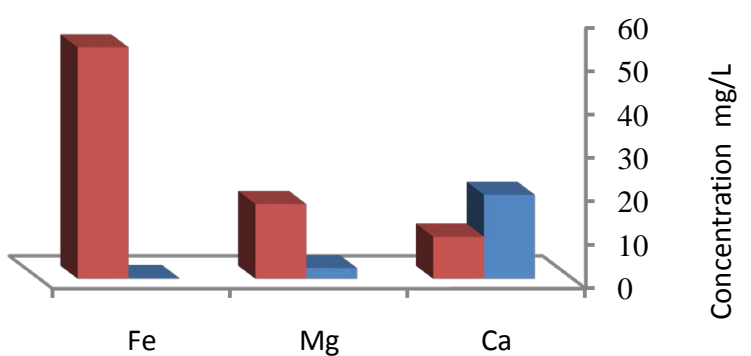

Elements

Port Sudan area Jabiat area

Figure 3. Elements average concentration of nails in different areas.

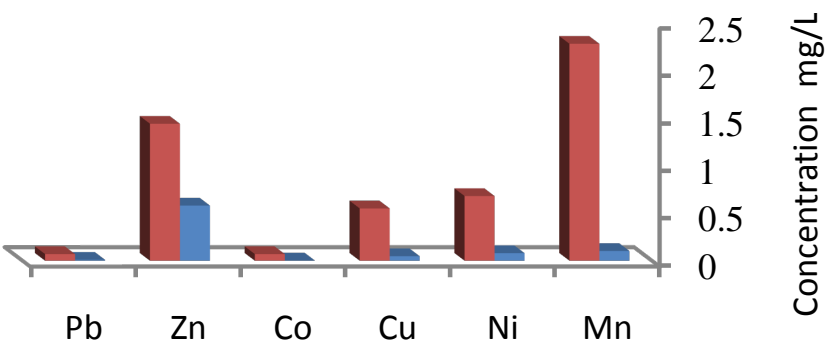

Elements

\section{- Port Sudan area Jabait area}

Figure 4. Elements average Cocentration of nails in different areas. 


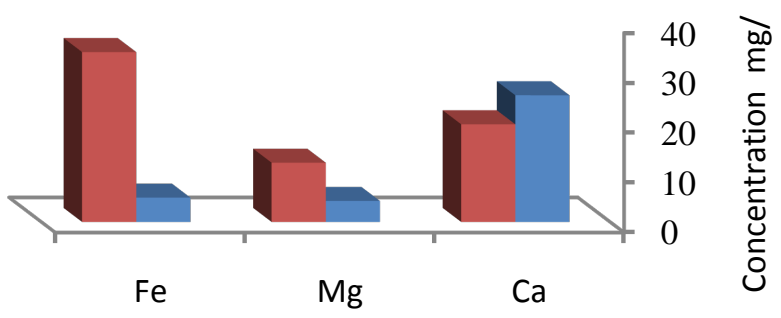

Elements

- Hands fingernails feet nails

Figure 5. Elements average concentration of nails.

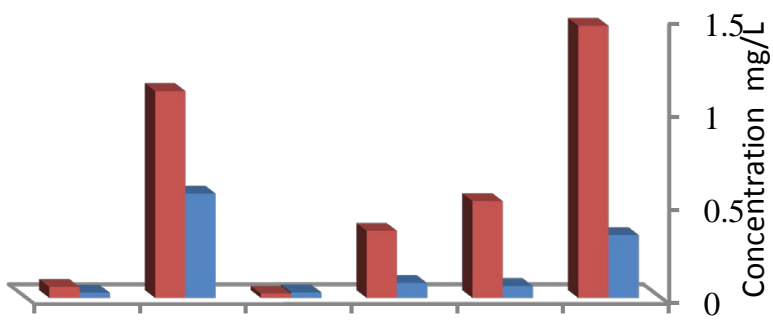

$\mathrm{Pb} \quad \mathrm{Zn} \quad \mathrm{Co} \quad \mathrm{Cu} \quad \mathrm{Ni} \quad \mathrm{Mn}$

Hands fingernails feet nails

Figure 6. Elements average concentration of nails.

more affected with soil dispersion, bacteria, human activities and other disease when compared to the hands fingernails. Therefore, the content in trace elements of the human nails are vary with locality sites and difference significantly between fingernails of hands and feet [13].

The data in Table 1 shows the correlations of nails elements contents and the marked correlations are significant at $\mathrm{p}<0.05$.

The behaviors of elements concentration in nails were explained by applying the principal component analysis in Table 2.

Therefore, the principal components analysis is categories two groups of elements and the data into three components for component matrix and rotated components matrix with varimax normalization.The relationship in Component (1) of $\mathrm{Mn}$ and $\mathrm{Mg}, \mathrm{Fe}, \mathrm{Cu}$ and $\mathrm{Zn}$ in nails is possible to be related to geographical exposure and underground drinking water. The data in rotated component matrix with varimax normalization is supporting the high value of $\mathrm{Mn}$ and $\mathrm{Mg}$, Fe, $\mathrm{Cu}$ and $\mathrm{Zn}$ in nails in Component (1).

The high value of $\mathrm{Ni}$ and $\mathrm{Pb}$ in Component (2) and intermediate value of $\mathrm{Ca}$ and $\mathrm{Ni}$ in Component (3) are possible to be connected to one source of environmental exposure.

The high value of $\mathrm{Pb}$ and negative value of $\mathrm{Ca}$ in Component (1) at varimax normalization and the high value of $\mathrm{Co}$ as in Component (3) is possible to be indication of different sources associated to environmental exposure for these four elements. The males and females nails elements concentration were illustrated extra of the $82.03 \%$ variance in hands fingernails elements concentration and $80.83 \%$ variance in feet nails elements concentration as comparative data.

The factors of principal component analysis in Table 3 and statistical data suggest that the higher value of Mn and $\mathrm{Mg}, \mathrm{Fe}, \mathrm{Cu}$ and $\mathrm{Zn}$ in fingernails were probably exposed to concentration in soil dispersion related to geographical location and underground drinking water.

$\mathrm{Mn}$ is highly correlated with (Mg, Fe, Zn) and moderate correlation with Co. Fe is highly correlated with (Mg, $\mathrm{Cu}$ ) and moderate correlation with $\mathrm{Co} . \mathrm{Zn}$ is in highly correlated with $(\mathrm{Mg}, \mathrm{Fe}, \mathrm{Cu})$ and moderate correlation with Co [20]. The extraction methods of principal components and communalities values indicates high values of $\mathrm{Mn}, \mathrm{Mg}, \mathrm{Fe}, \mathrm{Cu}$ and $\mathrm{Zn}$ which is excepted one group in factor1, while $\mathrm{Ca}$, Ni and $\mathrm{Co}$ of moderate values possible to be connected to one source [21]. 
Table 1. Shows the correlation between the elements concentration data of nails samples.

\begin{tabular}{|c|c|c|c|c|c|c|c|c|c|}
\hline & Ca & Mn & Mg & Fe & $\mathbf{N i}$ & $\mathrm{Cu}$ & Co & $\mathrm{Zn}$ & $\mathbf{P b}$ \\
\hline Ca & 1.00 & & & & & & & & \\
\hline Mn & -0.46 & 1.00 & & & & & & & \\
\hline Mg & -0.48 & 1.00 & 1.00 & & & & & & \\
\hline $\mathbf{F e}$ & -0.48 & 1.00 & 1.00 & 1.00 & & & & & \\
\hline $\mathrm{Ni}$ & -0.11 & 0.25 & 0.25 & 0.27 & 1.00 & & & & \\
\hline $\mathrm{Cu}$ & -0.50 & 0.99 & 1.00 & 1.00 & 0.26 & 1.00 & & & \\
\hline Co & -0.57 & 0.58 & 0.58 & 0.56 & 0.02 & 0.55 & 1.00 & & \\
\hline Zn & -0.63 & 0.94 & 0.94 & 0.94 & 0.32 & 0.95 & 0.66 & 1.00 & \\
\hline $\mathbf{P b}$ & -0.35 & -0.08 & -0.07 & -0.07 & 0.57 & -0.04 & 0.18 & 0.19 & 1.00 \\
\hline
\end{tabular}

Table 2. Principal analysis component matrix and rotated component matrix at varimax normalization.

\begin{tabular}{|c|c|c|c|c|c|c|}
\hline \multirow{3}{*}{ Elements } & \multicolumn{3}{|c|}{ Component Matrix } & \multicolumn{3}{|c|}{ Rotated Component Matrix. (Varimax Normalization) } \\
\hline & \multicolumn{3}{|c|}{ Component(1) } & \multicolumn{3}{|c|}{ Component(2) } \\
\hline & 1 & 2 & 3 & 1 & 2 & 3 \\
\hline Ca & -0.626 & -0.314 & 0.553 & -0.294 & -0.828 & -0.155 \\
\hline Mg & 0.971 & -0.177 & 0.148 & 0.974 & 0.219 & 0.020 \\
\hline Mn & 0.977 & -0.166 & 0.130 & 0.970 & 0.240 & 0.024 \\
\hline $\mathbf{F e}$ & 0.974 & -0.163 & 0.153 & 0.974 & 0.220 & 0.035 \\
\hline Ni & 0.309 & 0.707 & 0.578 & 0.283 & -0.155 & 0.909 \\
\hline $\mathrm{Cu}$ & 0.975 & -0.140 & 0.138 & 0.964 & 0.240 & 0.051 \\
\hline Co & 0.686 & 0.078 & -0.530 & 0.419 & 0.762 & -0.044 \\
\hline Zn & 0.981 & 0.072 & -0.013 & 0.861 & 0.437 & 0.187 \\
\hline $\mathbf{P b}$ & 0.096 & 0.949 & -0.106 & -0.205 & 0.418 & 0.839 \\
\hline
\end{tabular}

Table 3. Principal componentanalysis factors.

\begin{tabular}{|c|c|c|}
\hline Elements & Factor 1 & Factor 2 \\
\hline Ca & 0.391435 & 0.490213 \\
\hline Mn & 0.943411 & 0.974916 \\
\hline Mg & 0.953901 & 0.981555 \\
\hline $\mathbf{F e}$ & 0.947868 & 0.974575 \\
\hline $\mathrm{Ni}$ & 0.095540 & 0.596035 \\
\hline $\mathrm{Cu}$ & 0.950151 & 0.969728 \\
\hline Co & 0.470470 & 0.476549 \\
\hline Zn & 0.962438 & 0.967646 \\
\hline $\mathbf{P b}$ & 0.009136 & 0.910062 \\
\hline
\end{tabular}




\section{Conclusion}

Certainly, this is the first time to determined trace elements concentration in the nails of males and females in eastern Sudan related to geographical location, types of fingernails and environmental sources in the area. The correlation coefficient and principal component analysis are confirmed that the three groups of elements categorized due to the types of sources .However, these elements can be accumulated by direct external contamination related to environmental sources such as geographical location or indirect exposure due to types of food or drinking water [22]. Nails elements concentration in Port Sudan are more strongly coinciding variation with Jabiat, which is strong likelihood of significant external contamination linked to geographical location and underground drinking water and type of food, and activities in the cities [1]. Accordingly, the hands and feet fingernails elements concentration are differed probably due to external contamination exposure. On this regards, the statistical assessment of nails measurement is to identify potential problems as indicator for possible serious health effects and environmental contamination.

\section{References}

[1] Suhonen, R.E., Dawber, R. and Ellis, D.H. (1999) Fungal Infection of the Skin, Hair and Nails. Martin Dunitz, London.

[2] Kanabrocki, E.L., Kanabrocki, J.A., Greco, J., Kaplan, E. and Oester, Y.T. (1979) Instrumental Analysis of Trace Elements in Thumbnails of Human Subjects. Science of the Total Environment, 13, 131-140. http://dx.doi.org/10.1016/0048-9697(79)90067-6

[3] Abdulrahman, F.I., Akan, J.C., Chellube, Z.M. and Waziri, M. (2012) Levels of Heavy Metals in Human Hair and Nail Samples from Maiduguri Metropolis, Borno State, Nigeria. World Environment, 2, 81-89.

http://dx.doi.org/10.5923/j.env.20120204.05

[4] Garland, M., Morris, J.S., Rosner, B.A., Stamfer, M.J., Spate, V.L., Baskett, C.J., Willett, W.C., Hunter, D.J. (1993) Toenail Trace Element Levels as Biomarkers: Reproducibility over a 6-Year Period. Cancer Epidemiology Biomarkers Preview, 2, 493-497.

[5] Wilhem, M. and Hafner, D. (1991) Monitoring of Cadmium, Copper, Lead and Zinc Status in Young Children Using Toenails: Comparison with Scalp Hair. Science of Total Environmental, 103, 199-207. http://dx.doi.org/10.1016/0048-9697(91)90145-5

[6] Peters, K., Gammelgaard, B. and Menne, T. (1991) Nickel Concentrations in Fingernails as a Measure of Occupational Exposure to Nickel. Contact Dermatitis, 25, 237-241. http://dx.doi.org/10.1111/j.1600-0536.1991.tb01851.x

[7] Oluwole, A.F., Ojo, J.O., Durosinmi, M.A., Asubiojo, O.I., Akanle, O.A., Spyrou, N.M. and Filby, R.H. (1994) Elemental Composition of Head Hair and Fingernails of Some Nigerian Subjects. Biological Trace Elements Research, 43, 443-452. http://dx.doi.org/10.1007/BF02917346

[8] Hinwood, A.L. (2003) Hair and Toenail Arsenic Concentrations of Residents Living in Areas with, High Environmental Arsenic Concentrations. Environmental Health Perspectives, 111, 187-193.

[9] Biswas, S.K., Abdullah, M., Akhter, S., Tarafdar, S.A., Khaliquzzaman, M. and Khan, A.H. (1984) Trace Elements in Human Fingernails: Measurement by Proton-Induced X-Ray Emission. Journal of Radioanalytical Nuclear Chemistry, 82, 111-124.

[10] Sam, A.K. and Al-Geed, A.M.M. (2000) Radiological Evaluation of Gold Mining Activities in Ariab (Eastern Sudan). Radiation Protection Dosimetery (Technical Note), 88, 335-340.

[11] Rakib, M.A., et al., (2013) Arsenic Content in Inactive Tissue: Human Hair and Nail. Journal of Scientific Research \& Reports, 2, 522-535.

[12] Vance, D.E., et al., (1988) Trace Element Content in Fingernails and Hair of a Non-Industrialized US Control Population. Biological Trace Element Research, 17, 109-121.

[13] Mehra, R. and Juneja, M. (2005) Elements in Scalp Hair and Nails Indicating Metal Body Buren in Polluted Environment. Journal of Scientific and Industrial Research, 64, 119-124.

[14] Rao, K.S., Balaji, T. and PrasadaRao, T. (2002) Determination of Iron, Cobalt, Nickel, Manganese, Zinc, Copper, Cadmium and Lead in Human Hair by Inductively Coupled Plasma Atomic Emission Spectrometry. Spectrochimica Acta Part B, 57, 1333-1338. http://dx.doi.org/10.1016/S0584-8547(02)00045-9

[15] Biswas, S.K., Abdullah, M., Akhter, S., Tarafdor, S.A., Khaliquzzaman, M. and Khan, A.H. (1984) Trace Element Contents in Fingernails and Hair a Human. Journal of Radioanalytical Nuclear Chemistry, 82, 111-124. http://dx.doi.org/10.1007/BF02227334

[16] Rodushkin, I. and Axelsson, M.D. (2000) Application of Double Focusing Sector Field ICP-MS for Multi-Elemental 
Characterization of Human Hair and Nails. Part II, A Study of the Inhabitants of Northern Sweden. Science Total Environmental, 262, 21-36. http://dx.doi.org/10.1016/S0048-9697(00)00531-3

[17] Samanta, G., et al. (2004) Arsenic and Other Elements in Hair, Nails, and Skin-Scales of Arsenic Victims in West Bengal, India. Science of the Total Environment Elsevier, 326, 33-47. http://dx.doi.org/10.1016/j.scitotenv.2003.12.006

[18] Muralidharan, L. (2013) Nail as a Diagnostic Tool to Detect Heavy Metal Accumulation in Man Residing in Mumbai City and Their Impact on General Health. International Journal of Advanced Research, 1, 39-44.

[19] Othman, I. and Spyrou, N.M. (1980) The Abundance of Some Elements in Hair and Nail from the Machakos District of Kenya. Science of total Environmental, 16, 267-278. http://dx.doi.org/10.1016/0048-9697(80)90111-4

[20] Chowdary, K., Ehmann, W.D., Rengan, K. and Markesbery, W.R. (1995) Trace Elements Correlation with Age and Sex in Human Nails. Journal of Radioanalytical Nuclear Chemistry, 195, 51-66. http://dx.doi.org/10.1007/BF02036472

[21] Gammelgaard, B., Peters, K. and Menne, T. (1991) Reference Values for the Nickel Concentration in Human Finger nails. Journal of Trace Elements and Electrolytes in Health and Disease, 5, 121-123.

[22] Karagas, R.M., Tosteson, T.D. and Blum, J. (2000) Measurement of Low Levels of Arsenic Exposure: A Comparison of Water and Toenail Concentrations. American Journal of Epidemiology, 152, 84-90.

http://dx.doi.org/10.1093/aje/152.1.84 